\title{
SISTEM INFORMASI PELAYANAN PELANGGAN DAN KEPUASAAN PELANGGAN SEBAGAI PREDIKTOR TERHADAP KINERJA PERUSAHAAN PT. PLN (Persero) RAYON TANJUNGBATU
}

\author{
Afrizon Afrizon \\ Sekolah Tinggi Ilmu Ekonomi (STIE) Pembangunan Tanjungpinang \\ izonafr442@gmail.com
}

\begin{abstract}
Abstrak: Penelitian ini bertujuan untuk mengetahui apakah terdapat pengaruh dari sistem informasi pelayanan pelanggan, kepuasan pelanggan dan dimensi kualitas terhadap kinerja perusahaan. Untuk menjawab permasalahan ini terdapat empat hipotesis yang diajukan yang kesemuanya menunjukkan hasil signifikan terhadap kinerja perusahaan. Hasil analisis menunjukkan secara parsial baik sistem informasi pelayanan pelanggan, kepuasan pelanggan dan dimensi kualitas berpengaruh secara signifikan kinerja perusahaan. Demikian pula secara bersama-sama sistem informasi pelayanan pelanggan, kepuasan pelanggan dan dimensi kualitas berpengaruh signifikan dengan sumbangan determinasi sebesar $66,108 \%$, dengan persamaan regresi yaitu $\mathrm{Y}=-1,177+0,916 \mathrm{X} 1+0.230 \mathrm{X} 2+0,101 \mathrm{X} 3$. Berdasarkan penjelasan tersebut dapat dinyatakan bahwa semakin tinggi sistem informasi pelayanan pelanggan, kepuasan pelanggan dan dimensi kualitas maka semakin tinggi pula kinerja perusahaan PT PLN (persero) Rayon Tanjung Batu. Ini menunjukkan bahwa ketiga variabel dapat menjadi pengaruh yang baik dalam peningkatan kinerja perusahaan.
\end{abstract}

Kata Kunci: SIPP, Kepuasan pelanggan, dimensi kualitas, kinerja

Abstract: This study aims to determine whether there is an influence from customer service information systems, customer satisfaction and quality dimensions on company performance. To answer this problem, there are four hypotheses proposed, all of which show significant results on company performance. The results of the analysis show that partially both customer service information systems, customer satisfaction and quality dimensions have a significant effect on company performance. Simultaneously, customer service information systems, customer satisfaction and quality dimensions have a significant effect with a determination contribution of $66.108 \%$, with the regression equation $Y=-1.177+0.916 X 1+0.230 X 2+0.101 X 3$. Based on this explanation, it can be stated that the higher the customer service information system, customer satisfaction and quality dimensions, the higher the company performance of PT PLN (Persero) Rayon Tanjung Batu. This shows that the three variables can be a good influence in improving company performance.

Keywords: SIPP, customer satisfaction, quality dimensions, performance

\section{PENDAHULUAN}

Pembangunan nasional bertujuan untuk memajukan kesejahteraan umum dan mencerdaskan kehidupan bangsa, guna mewujudkan suatu masyarakat adil dan makmur yang merata baik materil maupun sprituil berdasarkan pancasila dan UUD 1945. Penyediaan tenaga listrik perlu diselenggarakan secara efisien melalui kompetisi dan transparansi dalam iklim usaha yang sehat dengan pengaturan yang memberikan perlakuan yang sama kepada semua pelaku usaha serta memberikan manfaat yang adil dan merata kepada konsumen.

Di Indonesia peningkatan taraf hidup masyarakat akibat adanya keberhasilan pembangunan yang dilakukan, dimana 
menimbulkan pula banyak perubahan dalam standar dan pola kehidupan masyarakat. Perubahanperubahan tersebut akan selalu diikuti dengan peningkatan kebutuhan daya listrik, karena masalah ini terkait dengan perubahan pola hidup masyarakat yang mempengaruhi pola konsumsi tenaga listrik.

Sistem informasi ketenagalistrikan masih menjadi barang yang mahal untuk dijadikan sebagai alat pembangunan. Walau perkembangan dan kemajuan dalam bidang kelistrikan terutama dalam dekade terakhir ini cukup pesat.

Salah satu diantaranya dalam bidang pengelolaan tenaga listrik mulai dari pembangkitan, transmisi, distribusi hingga pelayanan pelanggan yang utamanya ditujukan untuk memperoleh sistem yang aman, dengan mutu yang baik, tetapi dengan biaya yang efisien, efektif bermutu dan bisa diandalkan. Berarti dalam pembangkitan dan penyaluran energi itu harus dilakukan secara ekonomis dan rasional. Untuk mencapai tujuan itu ternyata dalam pengoperasioannya banyak kendala yang harus dihadapi. Pada perencanaan operasi sistem tenaga listrik yang baik dan akurat tentunya pengawasan selama beroperasi relatif perlu dilakukan. Perencanaan operasi itu sendiri adalah perencanaan bagaimana suatu sistem akan dioperasikan untuk jangka waktu tertentu (Marsudi D, 1990).

Menurut UU No.20 Tahun 2002 sistem ketenagalistrikan terdiri dari tiga bagian utama yaitu: Pusat Pembangkitan, Saluran
Transmisi dan Sistem Distribusi. Distribusi tenaga listrik adalah penyaluran tenaga listrik dari sistem transmisi atau dari sistem pembangkitan kepada konsumen. Pengoperasian sistem tenaga listrik adalah suatu usaha untu mengendalikan dan mengkoordinasikan antar sistem pembangkitan, transmisi dan distribusi tenaga listrik.

Untuk pengendalian operasi pada sistem tersebut perencanaan operasi perlu dilakukan dengan menggunakan berbagai teknik optimisasi agar dapat dicapai biaya operasi yang betul-betul dapat dipertanggungjawabkan.

Perusahaan Umum Listrik Negara (PLN) sebagai penyedia tunggal energi listrik di Indonesia, mulai kewalahan dalam melayani pelanggan dalam hal kebutuhan energi listrik. Ketersediaan sumber energi listrik tidak mampu memenuhi peningkatan kebutuhan listrik di Indonesia, pemutusan sementara dan pembagian energi secara bergilir tidak dapat dihindari yang berimbas terhadap penyuplaian energi listrik ke konsumen, dimana kualitas energi listrik yang diterima menurun (Haluan Kepri, 21 Agustus 2011).

Listrik kini sudah menjadi kebutuhan primer setiap masyarakat. Pihak penyedia energi tersebut harus berupaya menghargai pelanggan, seperti kata pepatah bahwa pelanggan adalah raja. Barangkali ada benarnya, suatu perusahaan tidak akan ada artinya, tanpa adanya pelanggan. Untuk perusahaan yang berwawasan pelanggan, 
kepuasan pelanggan adalah sasaran sekaligus kiat pemasaran.

Sebagai perusahaan yang bergerak dibidang kelistrikan penggunaan teknologi informasi tidak bisa dipisahkan dari proses pekerjaan yang dilakukan. Penggunaan teknologi informasi banyak dilakukan untuk menunjang proses pekerjaan. Kemudahan sistem informasi tagihan dan pembayaran dengan menggunakan sistem online merupakan salah satu bagian dari pengembangan sistem informasi yang dilakukan perusahaan. Akses komunikasi sampai ke pelosok dengan pemanfaatan infrastruktur komunikasi menggunakan teknologi informasi juga merupakan bagian dari pengembangan sistem informasi di tubuh perusahaan. Penggunaan sistem informasi dan teknologi informasi sudah menjadi keseharian dalam penerapan pekerjaan dan membantu proses pekerjaan perusahaan.

Dimensi kualitas yang dikemukakan oleh Zeithaml, Berry dan Parasuraman tersebut berpengaruh pada harapan pelanggan dan kenyataan yang mereka terima. Jika kenyataannya pelanggan menerima pelayanan melebihi harapannya, maka pelanggan akan mengatakan pelayanannya berkualitas dan jika kenyataannya pelanggan menerima pelayanan kurang atau sama dari harapannya, maka pelanggan akan mengatakan pelayanannya tidak berkualitas atau tidak memuaskan.
Mengingat begitu mendasarnya persoalan persediaan daya listrik ini, kebijakan Demand Side Management (DSM) yang dilakukan oleh PLN Pusat bertujuan untuk mengubah prilaku pelanggan agar menggunakan listrik secara efisien, baik pada besaran daya maupun waktunya yang akan memberikan manfaat bagi pelanggan, perusahaan listrik maupun masyarakat.

Atas dasar prilaku pelanggan dengan pelayanan yang diberikan oleh pihak perusahaan listrik negara itulah, maka tesis ini mengambil judul : "Sistem Informasi

Pelayanan Pelanggan dan Kepuasan Pelanggan Sebagai Prediktor Terhadap Kinerja Perusahaan PT. PLN (persero) Rayon Tanjung Batu"

\section{Perumusan Masalah}

Dari latar belakang tersebut, dapat dibuat suatu rumusan permasalahan sebagai berikut: 1. Apakah sistem informasi pelayanan pelanggan secara parsial berpengaruh signifikan terhadap kinerja perusahaan PT. PLN (persero) Rayon Tanjung Batu area Tanjung Pinang?

2. Apakah kepuasan pelanggan secara parsial berpengaruh signifikan terhadap kinerja perusahaan PT. PLN (persero) Rayon Tanjung Batu area Tanjung Pinang?

3. Apakah sistem informasi pelayanan pelanggan, kepuasan pelanggan secara simultan berpengaruh signifikan terhadap kinerja perusahaan PT. PLN (persero) Rayon Tanjung Batu area Tanjung Pinang? 
4. Apakah variabel dimensi kualitas (reliability, responsiveness, assurance, empathy, tangibles) secara simultan berpengaruh signifikan terhadap kinerja perusahaan?

\section{Batasan Masalah}

Berdasarkan perumusan masalah tersebut, masalah yang akan dibahas dalam penelitian ini adalah mengukur kinerja perusahaan dengan komponen variabel sistem informasi pelayanan pelanggan, kepuasan pelanggan dan dimensi kualitas dimana ketiga hal tersebut di uji dengan dengan menggunakan ukuran-ukuran statistik dan menganalisisnya sehingga didapat kesimpulan yang menunjukkan ukuran dari kedua penelitian tersebut. Adapun batasan masalah yang diangkat adalah sebagai berikut:

1. Sistem informasi pelayanan pelanggan yang digunakan adalah SIPP pada divisi pelayanan (SIPP Yan) .

2. Kepuasan pelanggan dimaksud adalah pelanggan yang tercatat pada sistem informasi pelayanan pelanggan.

\section{Tujuan Penelitian}

Adapun tujuan dari penelitian ini sebagaimana telah dijelaskan dalam latar belakang masalah adalah sebagai berikut :

1. Untuk menguji dan menggambarkan sistem informasi pelayanan pelanggan berpengaruh secara parsial terhadap kinerja perusahaan.
2. Untuk menguji dan menggambarkan kepuasan pelanggan berpengaruh secara parsial terhadap kinerja perusahaan.

3. Untuk menguji dan menggambarkan sistem informasi pelayanan pelanggan, kepuasan pelanggan berpengaruh secara simultan terhadap kinerja perusahaan.

4. Untuk menguji dan menggambarkan variabel dimensi kualitas (reliability, responsiveness, assurance, empathy, tangibles) secara simultan berpengaruh signifikan terhadap kinerja perusahaan.

\section{TINJAUAN PUSTAKA DAN PENGEMBANGAN HIPOTESIS \\ Sistim Informasi Pelayanan Pelanggan (Variabel X1).}

Sistem informasi pelayanan pelanggan diartikan dalam dua definisi menurut Endar Sugiarto dan Lupiyodi didefinisikan sebagai berikut :

Pengertian pelayanan menurut Endar Sugiarto (1999:36) mengungkapkan bahwa "Pelayanan adalah suatu tindakan yang dilakukan untuk memenuhi kebutuhan orang lain (konsumen, pelanggan, tamu, klien, pasien, penumpang dan lain-lain) yang tingkat pemuasannya hanya dapat dirasakan oleh orang yang melayani maupun yang dilayani.

Lupiyodi (2001:134) mendefinisikan Pelanggan adalah seorang individu yang secara continue dan berulang kali datang ke tempat yang sama untuk memuaskan keinginannya dengan memiliki suatu produk 
atau mendapatkan suatu jasa dan memuaskan produk atau jasa tersebut.

Kepuasan pelanggan (Variabel X2), Kotler (2003: 61) mendefinisikan kepuasan sebagai perasaan senang atau kecewa seseorang yang dialami setelah membandingkan antara persepsi kinerja atau hasil suatu produk dengan harapanharapannya.

Terdapat lima dimensi kualitas pelayanan menurut Parasuraman dalam Lupiyoadi (2001:148), yaitu: (1) Tangibles, (2) Reliability, (3) Responsiveness,

Assurance, (5) Empathy.

\section{Kinerja perusahaan (Variabel Y).}

Ruki (2001:14) menyatakan bahwa kinerja merupakan pengalihbahasaan dari istilah inggris 'performance', yang diartikan oleh Bernadin dan Russel "Performance is defined as the record, of outcomes produced on specified job function or activity during a specified time peiod" (kinerja adalah catatan tentang hasil-hasil yang diperoleh dari fungsifungsi pekerjaan tertentu atau kegiatan tertentu selama kurun waktu tertentu).

Selanjutnya Flippo (1984) mengatakan bahwa Kinerja adalah suatu hasil yang dicapai oleh para pekerja dalam pekerjaannya menurut kriteria tertentu yang berlaku untuk suatu pekerjaan tertentu dan dievaluasi oleh orang-orang tertentu.

\section{Kerangka Berpikir}

Berdasarkan kerangka berpikir tersebut dapat diajukan hipotesis penelitian ini adalah sebagai berikut :

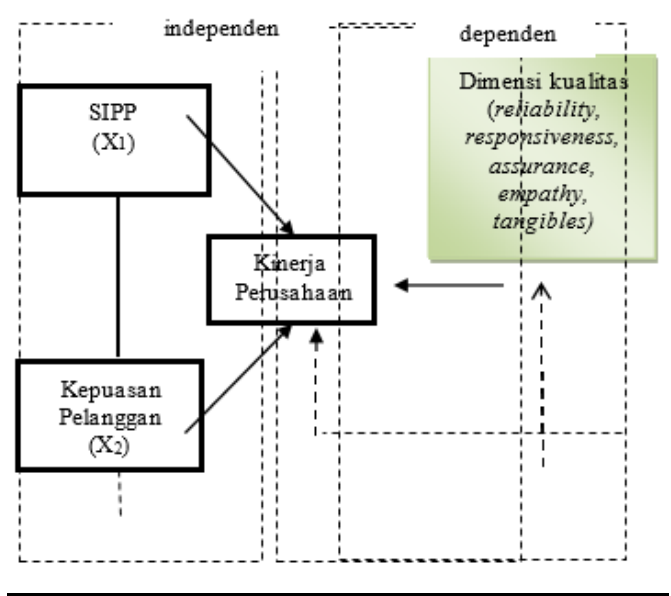

Grafik 1

Kerangka berpikir

1. Terdapat dampak yang positif dan signifikan antara sistem informasi pelayanan pelanggan terhadap kinerja perusahaan PT PLN (persero) Rayon Tanjung Batu Area Tanjung Pinang.

2. Terdapat dampak yang positif dan signifikan antara kepuasan pelanggan terhadap kinerja perusahaan PT PLN (persero) Rayon Tanjung Batu Tanjung Pinang.

3. Terdapat dampak yang positif dan signifikan antara sistem informasi pelayanan pelanggan dan kepuasan pelanggan secara bersama-sama terhadap kinerja perusahaan PT PLN (persero) Rayon Tanjung Batu Tanjung Pinang.

4. Terdapat dampak yang positif dan signifikan antara dimensi kualitas terhadap kinerja perusahaan PT PLN (persero) Rayon Tanjung Batu Tanjung Pinang.

\section{METODE PENELITIAN}

Kerangka dalam metodologi penelitian ini menggunakan metode survey, yaitu penelitian ini menggunakan teknik korelasional karena 
penelitian ini berusaha menyelidiki hubungan antara beberapa variabel penelitian yaitu variabel sistem informasi pelayanan pelanggan dan kepuasan pelanggan sebagai variabel predictor ditambah dengan variabel dimensi kualitas dengan kinerja perusahaan sebagai variabel criterion. Penelitian dilakukan di PLN (perseero) Rayon Tanjung Batu Area, Tanjung Pinang.

\section{Prosedur Pengumpulan Data}

Metode pengumpulan data yang dilakukan dalam penelitian ini adalah :

1) Kuesioner (angket)

Yaitu dengan cara menyebarkan daftar pertanyaan yang bersifat tertutup, yaitu daftar pertanyaan yang sudah disediakan alternatif jawabannya, sehingga dalam menjawab responden tinggal memilih salah satu di antara jawaban yang tersedia, yang dirasakan paling sesuai menurut pertimbangannya. Pertanyaan dibuat dengan menggunakan skala Likert, dan mempunyai penilaian apabila itemnya bernilai positif, maka penilaian untuk angka 5 untuk kategori sangat sesuai/sangat setuju, 4 sesuai/setuju, 3 tidak ada pendapat/ragu-ragu, 2 tidak sesuai/tidak setuju, 1 sangat tidak sesuai/sangat tidak setuju. Sedangkan apabila item bernilai negatif, penilaian dimulai angka terkecil yaitu 1 sangat sesuai/sangat setuju, 2 sesuai/setuju, 3 tidak ada pendapat/ragu-ragu, 4 tidak sesuai/tidak setuju, 5 sangat tidak sesuai/sangat tidak setuju.
2) Wawancara (interview).

Guna memberi penjelasan kepada responden tentang isi atau maksud daftar pertanyaan yang terdapat dalam kuesioner, serta untuk menggali informasi atau keterangan yang berkaitan dengan variabel penelitian, tetapi tidak tercakup dalam daftar pertanyaan (kuesioner/angket).

\section{3) Observasi}

Yaitu melakukan pengamatan secara langsung terhadap fenomena atau gejalagejala lain yang berhubungan dengan variabel penelitian, sehingga dapat melengkapi data dan pemahaman tentang variabel utama yang diteliti.

4) Dokumentasi

Teknik ini dilakukan dengan cara melihat dan mempelajari berbagai dokumen dan kepustakaan serta hasil-hasil penelitian yang berkaitan sehingga dapat memberikan perspektif yang lebih lengkap dan luas dalam memahami data variabel utama yang diteliti.

\section{Metode Analisis Data Validitas dan Reliabilitas Uji Validitas}

Dari hasil perhitungan validitas, dapat diketahui bahwa corrected item total correlation semua butir pertanyaan semua variabel lebih besar dari 0,05, dimana di dapat rhitung $=0,199$. Sehingga dapat dikatakan semua butir pertanyaan variabel dikatakan valid karena rhitung $>r$ table. 
Uji Reliabilitas

Tabel 1

Hasil Uji Reliabilitas

\begin{tabular}{llrr}
\hline & & $\mathrm{N}$ & $\%$ \\
\hline \multirow{2}{*}{$\mathrm{Ca}$} & Valid & 81 & 100.0 \\
\multirow{2}{*}{ ses } & Excluded $^{\mathrm{a}}$ & 0 & .0 \\
& Total & 81 & 100.0 \\
\hline
\end{tabular}

a. Listwise deletion based on all variables in the procedure.

\begin{tabular}{|l|c|c|}
\hline & $\begin{array}{c}\text { Cronbach } \\
\text { 's Alpha }\end{array}$ & N of Item \\
\hline SIPP $\left(\mathrm{X}_{1}\right)$ & .799 & 6 \\
\hline $\begin{array}{l}\text { Kepuasan } \\
\text { Pelanggan } \\
\left(\mathrm{X}_{2}\right)\end{array}$ & .879 & 11 \\
\hline $\begin{array}{l}\text { Dimensi } \\
\text { Kualitas }\left(\mathrm{X}_{3}\right)\end{array}$ & .868 & 13 \\
\hline $\begin{array}{l}\text { Kinerja } \\
\text { Perusahaan } \\
(\mathrm{Y})\end{array}$ & .840 & 5 \\
\hline
\end{tabular}

Sumber : diolah dari data primer

Pada Tabel di atas menunjukkan nilai cronbach's alpha variabel sistem informasi pelayanan pelanggan (SIPP) adalah sebesar $0,799>0,60$ berarti daftar pertanyaan yang terdiri dari 6 item pertanyaan tersebut adalah reliabel. Nilai cronbach's alpha variabel kepuasan pelanggan adalah sebesar $0,879>$ 0,60 berarti daftar pertanyaan yang terdiri dari 11 item pertanyaan tersebut adalah reliabel. Sedangkan variabel dimensi kualitas nilai cronbach's alpha $0,868>0,60$ berarti daftar pertanyaan yang terdiri dari 13 item pertanyaan tersebut adalah reliabel. Dan untuk variabel kinerja perusahaan yang terdiri dari 5 item pertanyaan juga lebih besar dari cronbach's alphanya.

\section{Uji Asumsi Klasik}

\section{Multikolonieritas}

Multikolonieritas muncul apabila antara variabel-variabel bebas memiliki hubungan yang sangat luas, dengan kata lain, diantara variabel-variabel bebas berkorelasi sempurna atau mendekati sempurna. Untuk mendeteksi ada atau tidaknya multikolonieritas dapat dilakukan dengan cara melihat nilai variance inflation factor (VIF) antara variabel-variabel bebas.

Selanjutnya hasil perhitungan dibandingkan, apabila nilai VIF masingmasing variabel bebas lebih besar 10 maka tedapat derajat multikolonieritas yang tinggi (Sumodiningrat, 1999:286). Hasil data analisis diperoleh dari nilai variance inflation factor (VIF) sebagai berikut :

Tabel 2

Hasil Uji Multikolonieritas

\begin{tabular}{|c|c|c|}
\hline Variabel & VIF & Keterangan \\
\hline $\mathrm{X}_{1}$ & 1,507 & $\begin{array}{c}\text { tidak terjadi } \\
\text { multikolonieritas } \\
\text { tidak terjadi } \\
\mathrm{X}_{2}\end{array}$ \\
$\mathrm{X}_{3}$ & 1,767 & $\begin{array}{c}\text { multikolonieritas } \\
\text { tidak terjadi } \\
\text { multikolonieritas }\end{array}$ \\
\hline
\end{tabular}

Sumber : Data Primer setelah diolah

\section{Autokorelasi}

Autokorelasi terjadi apabila ada gejala korelasi serial diantara data pengamatan. Hal ini bisa muncul karena adanya pengaruh dari data sebelumnya (untuk data time series) atau data pengamatan menurut tempat (untuk data crossection). Pendeteksiannya dilakukan 
dengan Durbin Watson Test (D). jika nilai Durbin-Watson (d) berada di sekitar 2 atau berada di antara 1 sampai dengan 3 maka tidak terdapat gejala autokorelasi.

Tabel 3

Hasil Uji Autokorelasi

Model Summary ${ }^{b}$

Mo R R Adju Std. Durbindel Square sted Error of Watson

$$
\begin{aligned}
& \mathrm{R} \text { the } \\
& \text { Squa Estimate re }
\end{aligned}
$$

\begin{tabular}{llllll}
1 & $.849^{\mathrm{a}}$ & .720 & .709 & .30311 & 2.109 \\
\hline
\end{tabular}

a. Predictors: (Constant), X3RATA, X1RATA, X2RATA

b. Dependent Variable: Y1RATA

Berdasarkan hasil analisis diperoleh nilai Durbin Watson $(\mathrm{d})=2,109$ dimana nilainya di sekitar 2 atau berada di antara 1 sampai dengan 3 artinya tidak terjadi autokorelasi

\section{Heteroskedastisitas}

Dari grafik scatterplot yang disajikan terlihat titik-titikj menyebar secara acak tidak membentuk sebuah poa tertentu yang jelas serta tersebar baik di atas maupun di bawah angka nol pada sumbu $\mathrm{Y}$ hal ini berarti tidak terjadi heterokedastisitas pada model regresi, sehingga model regresi layak dipakai untuk memprediksi prestasi belajar berdasarkan masukan variabel independennya.

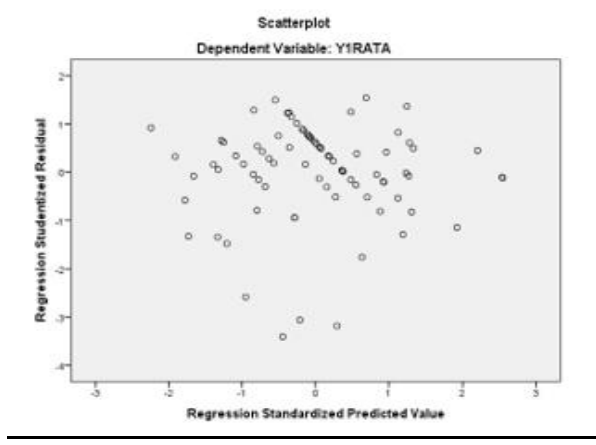

Grafik 2

Scatterplot Kinerja Perusahaan (Y)

\section{Analisis Regresi}

Hasil analisis regresi linier berganda dapat disusun dalam bentuk persamaan regresi berganda sebagai berikut : $\mathrm{Y}=\alpha+\beta 1 \mathrm{X} 1+$ $\beta 2 \mathrm{X} 2+\beta 3 \mathrm{X} 3+\epsilon$

Tabel 4

Hasil Analisis Regresi

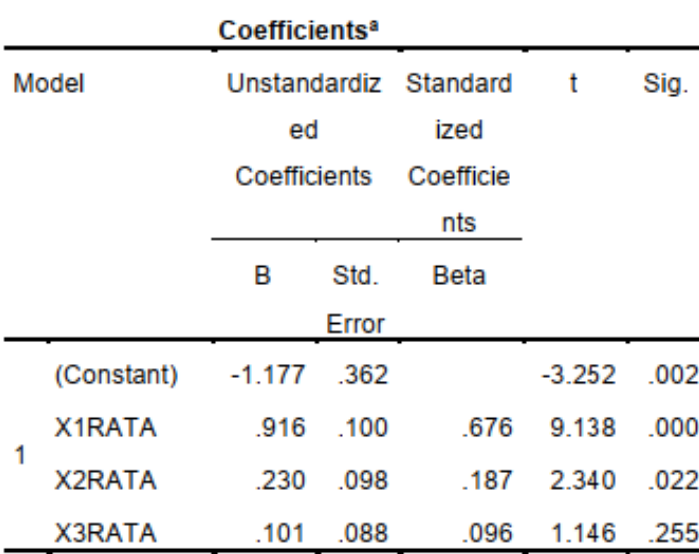

a. Dependent Variable: Y1RATA

$$
\begin{gathered}
\mathrm{Y}=-1,177+0,916 \mathrm{X}_{1}+0.230 \mathrm{X}_{2}+ \\
0,101 \mathrm{X}_{3}
\end{gathered}
$$

Konstanta sebesar -1,177 menunjukkan nilai variabel kinerja perusahaan, jika tidak ada pengaruh variabel sistem informasi pelayanan pelanggan, kepuasan pelanggan dan dimensi kualitas.

Nilai koefisien regresi variabel sistem informasi pelayanan pelanggan diperoleh sebesar 0,916 menunjukkan besarnya pengaruh variabel sistem informasi pelayanan 
pelanggan terhadap kinerja perusahaan, dimana pengaruhnya positif (searah) artinya semakin meningkat sistem informasi pelayanan pelanggan yang digunakan akan menyebabkan semakin tinggi kinerja perusahaan dan sebaliknya. Sedangkan nilai koefisien regresi variabel kepuasan pelanggan sebesar 0,230 menunjukkan besarnya pengaruh variabel kepuasan pelanggan terhadap kinerja perusahaan dan pengaruhnya positif (searah). Artinya semakin tinggi kepuasan pelanggan akan menyebabkan semakin tinggi kinerja perusahaan dan sebaliknya.

Sedangkan nilai koefisien regresi variabel dimenasi kualitas sebesar 0,101 menunjukkan besarnya pengaruh variabel dimensi kualitas terhadap kinerja perusahaan dan pengaruhnya positif (searah). Artinya semakin tinggi dimensi kualitas akan menyebabkan semakin tinggi kinerja perusahaan dan sebaliknya.

Setiap peningkatan skor sistem informasi pelayanan pelanggan satu satuan maka kinerja perusahaan meningkat 0,916 satuan.

Setiap peningkatan skor kepuasan pelanggan satu satuan maka kinerja perusahaan meningkat 0,230 satuan.

Setiap peningkatan skor dimensi kualitas satu satuan maka kinerja perusahaan meningkat 0,101 satuan.

Nilai Sig. Untuk variabel sistem informasi pelayanan pelanggan adalah $0,000<\alpha=0,05$. Artinya pengaruh sistem informasi pelayanan pelanggan terhadap kinerja perusahaan signifikan.
Sedangkan nilai Sig. Untuk variabel kepuasan pelanggan dan dimensi kualitas adalah 0,022 dan 0,255 lebih besar dari $>\alpha=$ 0,05 artinya bahwa kepuasan pelanggan dan dimensi kualitas tidak signifikan.

Tabel 5

Koefisien Determinasi dan Korelasi

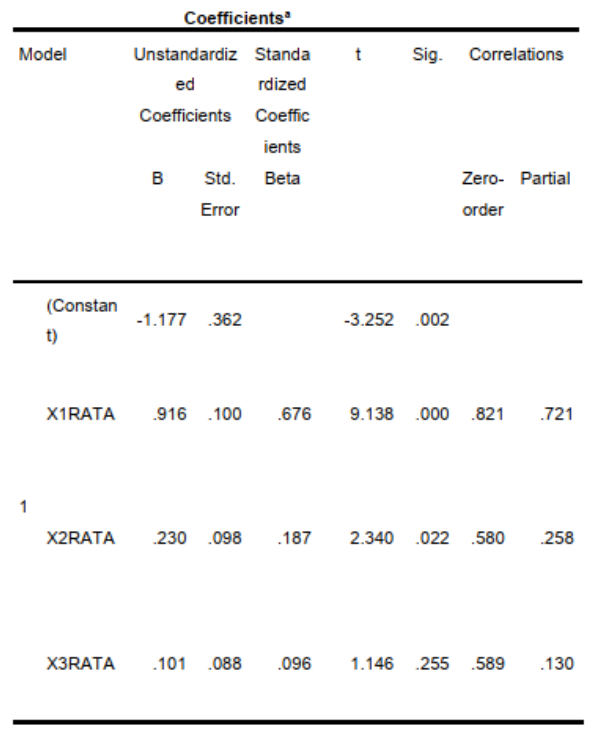

a. Dependent Variable: Y1RATA

Koefisien korelasi parsial sistem informasi pelayanan pelanggan dengan kinerja perusahaan $\left(\mathrm{r}_{\mathrm{y} 123}\right)=0,721$, artinya secara parsial terjadi hubungan positif yang kuat. Koefisien korelasi parsial kepuasan pelanggan dengan kinerja perusahaan $\left(\mathrm{r}_{\mathrm{y} 123}\right)=$ 0,258, artinya Model secara parsial terjadi hubungan positif yang rendah.

Sedangkan koefisien korelasi parsial dimensi kualitas dengan kinerja perusahaan $\left(\mathrm{r}_{(} \mathrm{y} 123\right.$ Constant $\left.)=0,130, \quad\right)$ artinya secara parsial terjadi hubungan positif ${ }_{1}{ }^{\text {X1TOT }}$ yang sangat rendah. 
Hasil Uji Hipotesis

1. Hasil Uji Hipotesis I

Tabel 6

Hasil Uji Hipotesis I

\begin{tabular}{|c|c|c|c|c|c|c|}
\hline \multicolumn{7}{|c|}{ ANOVA $^{a}$} \\
\hline \multicolumn{2}{|c|}{ Model } & Sum of & Df & Mean & $\mathrm{F}$ & Sig. \\
\hline \multirow{3}{*}{1} & Regression & 18.221 & 3 & 6.074 & 66.108 & $.000^{\circ}$ \\
\hline & Residual & 7.075 & 77 & .092 & & \\
\hline & Total & 25.296 & 80 & & & \\
\hline
\end{tabular}

Pengujian hipotesis pertama

dengan $\alpha=5 \%$ diperoleh nilai Fhitung = 66,108 sedangkan nilai Ftabel $=3,109$

Jadi F Fhitung > Ftabel, dan probabilitas (sig) sebesar $0,000<0,05$ sehingga $\mathrm{H} 0$ ditolak. Jadi secara simultan variabel sistem informasi pelayanan pelanggan, kepuasan pelanggan dan dimensi kualitas berpengaruh secara signifikan terhadap kinerja perusahaan.

2. Hasil Uji Hipotesis II

Tabel 7

Hasil uji hipotesis II

\begin{tabular}{|c|c|c|c|c|c|c|}
\hline \multirow[b]{2}{*}{ : } & \multirow[t]{2}{*}{ Model } & \multicolumn{2}{|c|}{$\begin{array}{c}\text { Unstandardized } \\
\text { Coefficients }\end{array}$} & \multirow{2}{*}{$\frac{\begin{array}{c}\text { Standardized } \\
\text { Coefficients }\end{array}}{\text { Beta }}$} & \multirow[t]{2}{*}{$t$} & \multirow[t]{2}{*}{ Sig. } \\
\hline & & B & $\begin{array}{l}\text { Std. } \\
\text { Error }\end{array}$ & & & \\
\hline 1 & (Constant) & -6.044 & 1.811 & & -3.337 & .001 \\
\hline$l_{1}$ & Х1TOT & .772 & .084 & .679 & 9.179 & .000 \\
\hline & Х2TOT & .100 & .044 & .179 & 2.256 & .027 \\
\hline & ХзТоТ & .041 & .034 & .101 & 1.209 & .230 \\
\hline
\end{tabular}

Hasil pengujian variabel bebas sistem informasi pelayanan pelanggan, kepuasan pelanggan dan dimensi kualitas terhadap kinerja perusahaan dapat dijelaskan sebagai berikut :

a. Sistem informasi pelayanan pelanggan SIPP $\left(\mathrm{X}_{1}\right)$ ditunjukkan dengan nilai $\mathrm{t}_{\text {hitung }}$ sebesar 9,179 lebih besar dari $t_{\text {tabel }}=$ 1,990 berarti signifikan terhadap kinerja perusahaan, dan nilai signifikansi 0,000 lebih kecil dari 0,05.

b. Kepuasan pelanggan $\left(\mathrm{X}_{2}\right)$ ditunjukkan dengan nilai dengan nilai thitung sebesar 2,256 lebih besar dari $t_{\text {tabel }}=1,990$ berarti signifikan terhadap kinerja perusahaan, dan nilai signifikansi 0,027 lebih kecil dari 0,05.

c. Dimensi kualitas $\left(\mathrm{X}_{3}\right)$ ditunjukkan dengan nilai dengan nilai $t_{\text {hitung }}$ sebesar 1,209 lebih kecil dari $t_{\text {tabel }}=1,990$ berarti tidak signifikan terhadap kinerja perusahaan, dan nilai signifikansi 0,230 lebih besar dari 0,05 .

Berdasarkan hasil uji $\mathrm{t}$ dapat diketahui bahwa variabel sistem informasi pelayanan pelanggan, kepuasan pelanggan dan dimensi kualitas secara parsial berpengaruh positif terhadap kinerja perusahaan dengan demikian hipotesis II yang diajukan dapat diterima.

3. Hasil Uji Hipotesis III

Tabel 8

Hasil Uji Hipotesis III

\begin{tabular}{|c|c|c|c|c|c|}
\hline \multirow[t]{2}{*}{ Model } & \multicolumn{2}{|c|}{$\begin{array}{l}\text { Unstandardized } \\
\text { Coefficients }\end{array}$} & \multirow{2}{*}{$\begin{array}{c}\text { Standardize } \\
\text { d } \\
\text { Coefficients } \\
\text { Beta }\end{array}$} & \multirow[t]{2}{*}{$\mathrm{t}$} & \multirow[t]{2}{*}{ Sig. } \\
\hline & B & $\begin{array}{l}\text { Std. } \\
\text { Error }\end{array}$ & & & \\
\hline (Constant) & -1.177 & .362 & & -3.252 & .002 \\
\hline \multirow{3}{*}{$\begin{array}{l}1 \text { X1RATA } \\
\text { X2RATA } \\
\text { X3RATA }\end{array}$} & .916 & .100 & .676 & 9.138 & .000 \\
\hline & .230 & .098 & .187 & 2.340 & .022 \\
\hline & 101 & .088 & .096 & 1.146 & .255 \\
\hline
\end{tabular}

Pengujian hipotesis III adalah untuk mengetahui variabel bebas yang 
berpengaruh dominan terhadap variabel terikat dengan membandingkan koefisien beta atau koefisien regresi yang distandarisasi diantara masing-masing variabel bebas.

Koefisien beta variabel sistem informasi pelayanan pelanggan sebesar 0,676 menunjukkan besarnya pengaruh sistem informasi pelayanan pelanggan terhadap kinerja perusahaan dengan pengaruh yang searah, artinya sistem informasi pelayanan pelanggan yang ditunjukkan dengan indikator tersebut menyebabkan semakin tinggi kinerja perusahaan dengan menganggap variabel lain tetap.

Koefisien beta variabel kepuasan pelanggan sebesar 0,187 menunjukkan besarnya pengaruh kepuasan pelanggan terhadap kinerja perusahaan dengan pengaruh yang searah, artinya kepuasan pelanggan yang ditunjukkan dengan indikator menyebabkan semakin tinggi kinerja perusahaan dengan menganggap variabel lain tetap.

Koefisien beta variabel dimensi kualitas sebesar 0,096 menunjukkan besarnya pengaruh dimensi kualitas terhadap kinerja perusahaan dengan pengaruh searah. Artinya dimensi kualitas yang ditunjukkan dengan indikator menyebabkan semakin tinggi kinerja perusahaan dengan variabel lain tetap.

Dengan demikian dari hasil koefisien beta variabel sistem informasi pelayanan pelanggan, kepuasan pelanggan dan dimensi kualitas ternyata koefisien beta variabel sistem informasi pelayanan pelanggan memiliki nilai koefisien beta lebih besar dibandingkan variabel kepuasan pelanggan dan dimensi kualitas, dengan demikian variabel sistem informasi pelayanan pelanggan SIPP merupakan variabel yang berpengaruh dominan terhadap kinerja perusahaan PT. PLN (persero) Rayon Tanjung Batu, sehingga hipotesis ketiga yang diajukan dapat diterima.

1. Pembahasan

Deskripsi dari masing-masing variabel diukur dari pernyataan responden terhadap kuisioner yang diajukan menunjukkan bahwa tingkat pelayanan PT PLN (persero) Rayon Tanjung Batu yang diukung dengan variabel dimensi kualitas dianggap sudah baik. Hal ini dapat diketahui dari sebagian besar responden yang merasa bahwa penggunaan sistem informasi pelayanan pelanggan dengan didukung dimensi kualitas dianggap baik.

Responden merasa bahwa sistem informasi pelayanan pelanggan dengan beberapa indikator tersebut sudah sesuai dengan harapan dan peningkatan kinerja dalam mengelola perusahaan dan sesuai dengan peran masing-masing bagian. Kesediaan responden untuk mengisi dan menjawab kuisioner dengan pernyataan bahwa sistem informasi pelayanan pelanggan yang terdiri dari keyakinan atas pelayanan dan kepedulian atas pelayanan menunjukkan nilai yang baik. Rasa aman, komunikatif dan akomodatif dalam melayani pelanggan memberikan penilaian tersendiri baik dimana pelanggan maupun karyawan karena itu 
menunjukkan nilai yang bagus. Kemudian didukung dengan pengetahuan, perhatian dan memahami dengan baik bagaimana menyelesaikan setiap persoalan yang dihadapi pelanggan juga mendapatkan hasil yang baik dan ditunjukkan dengan nilai yang baik di mata responden.

Deskripsi variabel kepuasan pelanggan yang ditunjukkan dengan beberappa indikator seperti keandalan karyawan, penampilan dan daya tanggap memiliki nilai yang cukup baik walau ratarata masih dibawah nilai variabel pertama.. Variabel ini yang terdiri dari indikator seperti keandalan karyawan dimana kemampuan karyawan yang dapat diandalkan dalam menangani pelanggan cukup menggembirakan dimata responden dengan berbagai jawaban yang mempunyai rata-rata yang baik.

Pernyataan mengenai penampilan bahwa PT PLN (persero) Rayon Tanjung Batu mempunyai peralatan yang memadi dan sudah sesuai standar yang dianggap canggih dalam menangani persoalan mendapat respon jawaban setuju sebanyak $60,5 \%$ dari jumlah responden. Kemudian pernyataan mengenai fasilitas fisik perusahaan sangat menarik juga mendapatkan hasil jawaban yang memuaskan dari sebanyak $61,7 \%$ menyatakan setuju bahwa fasilitas sangat menarik minat pelanggan untuk diberikan kemudahankemudahan dalam proses pembayaran tagihan. Sedangkan beberapa item dari indikator ketiga dari kepuasan pelanggan yang ditunjukkan dengan item dari pernyataan juga mendapatkan jawaban baik dari responden. Hal ini terbukti dengan jumlah pernyaatan yang sebagian besar menjawab setuju atas indikator dari pertanyaan variabel tersebut.

Dimensi kualitas yang merupaka variabel pembantu dan penghubung dan dimasukkan juga ke dalam variabel ketiga memiliki nilai yang baik dimata responden. Hal ini ditunjukkan dari hasil nilai yang didapat dari pernyataan jawaban responden memiliki nilai yang cukup baik. Selain memiliki nilai yang paling cukup diantara dua variabel lainnya namun terdapat juga yang menyatakan percaya dengan memberikan pernyataan sangat setuju sebanyak $25,9 \%$ untuk pernyataan bahwa PT PLN (persero) Rayon Tanjung Batu memberi jaminan pencatatan meter arus listrik dengan tepat. Hal ini memang sangat riskan karena model pencatatan seringkali mengalami banyak masalah ketidakakuratan hasil data pencatatan yang dilakukan para pencatat meter. Jaminan yang diberikan perusahaan menumbuhkan kepercayaan dimata responden dengan nilai yang baik.

Kinerja perusahaan sebagai variabel yang terikat juga memberikan nilai yang sangat baik di mata responden. Jawaban responden terbesar sebesar $56,8 \%$ di dapat dari pernyataan mengenai jasajasa yang diberikan perusahaan menguntungkan para pelanggan. Dimana diketahui bahwa PT PLN (persero) Rayon Tanjung Batu melakukan kerjasama dengan beberapa unit satuan kerja 
masyarakat untuk membuka loket-loket pembayaran tagihan. Dan hal ini sangat membantu pelanggan yang berada jauh dari jangkauan unit pembayaran perusahaan yang tersebar di beberapa titik lokasi yang ramai. Dengan demikian deskripsi kinerja perusahaan yang diukur berdasarkan item pertanyaan sebagian besar memiliki hasil yang baik.

Dengan demikian item-item pertanyaan dari variabel bebas dan satu variabel terikat dalam penelitian ini telah memberikan jawaban yang memuaskan dari adanya pengaruh dan keterikatan variabel-variabel tersebut. Hasil pembahasan menunjukkan bahwa variabel sistem informasi pelayanan pelanggan, kepuasan pelanggan dan dimensi kualitas berpengaruh secara signifikan dengan variabel sistem informasi pelayanan pelanggan yang paling dominan mempengaruhi kinerja perusahaan PT PLN (persero) Rayon Tanjung Batu.

\section{Pembahasan Hasil Uji Hipotesis I}

Dari hasil pengujian hipotesis I teruji bahwa secara simultan variabel sistem informasi pelayanan pelanggan, kepuasan pelanggan dan dimensi kualitas berpengaruh secara signifikan terhadap kinerja perusahaan PT PLN (persero) Rayon Tanjung Batu, yang ditunjukkan dengan nilai $F_{\text {hitung }}>F_{\text {tabel }}$ dan probabilitas lebih kecil dari 0,05. Berarti bahwa sistem informasi pelayanan pelanggan yang tercermin dari adanya keyakinan atas pelayanan dan kepedulian atas pelayanan maka mengakibatkan kinerja perusahaan PT
PLN (persero) Rayon Tanjung Batu akan meningkat. Perubahan kinerja perusahaan sebesar 66,108\% disebabkan oleh adanya sistem informasi pelayanan pelanggan, kepuasan pelanggan dan dimensi, sedangkan sisanya disebabkan oleh variabel lain yang tidak diteliti, diduga variabel lain yang tidak diteliti tersebut sangat berpengaruh terhadap kinerja perusahaan.

\section{Pembahasan Hasil Uji Hipotesis II}

Hasil pengujian regresi secara parsial menunjukkan bahwa variabel sistem informasi pelayanan pelanggan yang meliputi indikator keyakinan atas pelayanan dan kepedulian atas pelayanan serta variabel kepuasan pelanggan yang meliputi keandalan karyawan, penampilan dan daya tanggap menambah produktivitas dan efektivitas serta mengembangkan kinerja pekerjaan yang berpengaruh positif terhadap kinerja perusahaan PT PLN (persero) Rayon Tanjung Batu. Hal ini dapat dilihat dari nilai-nilai $t_{\text {hitung }}$ $>t_{\text {tabel }}$ dan probabilitas lebih kecil dari 0,05.

\section{Pembahasan Hasil Uji Hipotesis III}

Pengujian hipotesis ketiga teruji bahwa variabel sistem informasi pelayanan pelanggan memliki pengaruh yang paling dominan terhadap kinerja perusahaan PT PLN (persero) Rayon Tajung Batu. Hal ini dapat dilihat dari nilai koefisien regresi yang sudah distandarisasi variabel sistem informasi pelayanan pelangga memiliki nilai paling besar dibandingkan dengan kedua variabel lain yaitu kepuasan pelanggan dan dimensi kualitas 


\section{PENUTUP}

\section{Kesimpulan}

Dari hasil pembahasan yang telah dilakukan pada bab sebelumnya dapat ditarik kesimpulan sebagai berikut :

1. Dari hasil analisis regresi diketahui bahwa

a) Terdapat pengaruh yang signifikan antara sistem informasi pelayanan pelanggan, kepuasan pelanggan dan dimensi kualitas secara bersama-sama terhadap kinerja perusahaan PT PLN (persero) Rayon Tanjung

b) Batu, dengan nilai Fhitung $=66,108$, sedangkan nilai Ftabel $=3,109$

c) Terdapat pengaruh sistem informasi pelayanan pelanggan terhadap kinerja perusahaan PT PLN (persero) Rayon Tanjung Batu secara parsial ditunjukkan dengan nilai thitung sebesar 9,179 lebih besar dari ttabel $=1,990$ yang berarti signifikan.

d) Terdapat pengaruh kepuasan pelanggan terhadap kinerja perusahaan PT PLN (persero) Rayon Tanjung Batu secara parsial ditunjukkan dengan nilai nilai thitung sebesar 2,256 lebih besar dari ttabel $=1,1990$ yang berarti signifikan.

e) Terdapat pengaruh dimensi kualitas terhadap kinerja perusahaan PT PLN (persero) Rayon Tanjung Batu secara parsial ditunjukkan dengan nilai thitung sebesar 1,209 lebih kecil dari ttabel = 1,990 yang berarti tidak signifikan.

2. Dari hasil analisis korelasi diketahui bahwa a) Terdapat hubungan yang signifikan antara sistem informasi pelayanan pelanggan terhadap kinerja perusahaan PT PLN (persero) Rayon Tanjung Batu dengan signifikansi 0,721 yang berarti korelasi kuat.

b) Terdapat hubungan yang signifikan antara kepuasan pelanggan terhadap kinerja perusahaan PT PLN (persero) Rayon Tanjung Batu dengan signifikansi 0,258 yang berarti korelasi rendah.

c) Terdapat hubungan yang signifikan antara dimensi kualitas terhadap kinerja perusahaan PT PLN (persero) Rayon Tanjung Batu dengan signifikansi 0,130 yang berarti korelasi sangat rendah.

3. Maka didapat kesimpulan bahwa :

a) Hipotesis yang menyatakan bahwa terdapat pengaruh yang signifikan antara sistem informasi pelayanan pelanggan, kepuasan pelanggan dan dimensi kualitas terhadap kinerja perusahaan PT PLN (persero) Rayon Tanjung Batu adalah terbukti.

b) Hipotesis yang menyatakan bahwa terdapat hubungan yang signifikan antara sistem informasi pelayanan pelanggan, kepuasan pelanggan dan dimensi kualitas terhadap kinerja perusahaan PT PLN (persero) Rayon Tanjung Batu adalah terbukti.

\section{Saran}

Dari hasil analisis data dan hasil kesimpulan tersebut, maka disarankan untuk 
peningkatan pelayanan perusahaan sebagai berikut :

1) Untuk meningkatkan kinerja perusahaan perlunya diterapkan penggunaan sistem informasi pelayanan pelanggan dengan mengedepankan persoalan teknologi informasi sebagai basis kemajuan perusahaan dan yang merupakan faktor terpenting untuk mengejar ketertinggalan demi kepuasan pelanggan.

2) Pihak perusahaan hendaknya memperhatikan mengenai ketiga variabel penelitian terhadap kinerja perusahaan karena hubungan yang terjadi dengan kinerja perusahaan ternyata masih relative lemah, tetapi hal ini masih bisa dimaksimalkan..

3) Karena ada hubungan positif tetapi lemah sangat lemah yang telah dijelaskan dari hasil penelitian, maka penulis memberi saran kepada peneliti berikutnya untuk menjadikan perhatian mengenai variabel bebas dan kalimat-kalimat dari item kuisioner karena untuk mendapatkan jawaban yang terbaik bagi responden.

\section{DAFTAR PUSTAKA}

Achmad., 2001. Sistem Analisis Kinerja. Jakarta: Gramedia

Azhar., 2007. Faktor-faktor yang mempengaruhi keberhasilan penerapan permendagri No. 13 pada Pemerintah Kota Banda Aceh. Medan : Program Pasca Sarjana Universitas Sumatera Utara

Barnes, J.G., 2003. Secrets of Customer Relationship Management (Rahasia Manajemen Pelanggan). Yogyakarta: Andi.
Bobbi, D. and Hernacki, M., 2002. Quantum learning membiasakan belajar nyaman dan menyenangkan. Bandung: Kaifa.

Ghozali, I., 2005. Aplikasi Analisis Multivariate dengan program SPSS edisi 3. Semarang: Badan Penerbit Universitas Diponegoro.

Handoko, T.H., 2003. Manajemen, Cetakan Kedelapan belas. Yogyakarta: BPFE.

Hasibuan, M.S., 2005. Manajemen sumber daya manusia, edisi revisi. Bumi Aksara, Jakarta, 288.

Horne, J.C.V. and Wachowicz, J.M., 2012. Prinsip-prinsip manajemen keuangan. Jakarta: Salemba Empat.

Indriantoro, N. and Supomo, B., 2002. Metodologi penelitian bisnis: untuk akuntansi \& manajemen.

Jogiyanto, H.M., 2017. Analisis dan Desain (Sistem Informasi Pendekatan Terstruktur Teori dan Praktek Aplikasi Bisnis). Penerbit Andi.

Kotler, P. and Pemasaran, M., 2002. edisi Milenium. Manajemen Pemasaran.

Kuswadi., 2004. Cara Mengukur Kepuasan Karyawan. Jakarta : PT. Alex Media Komputindo.

Mangkunegara, A.A.P., 2005. Evaluasi kinerja SDM. Tiga Serangkai.

Nasution, M.N., 2004. Manajemen jasa terpadu. Bogor: Ghalia Indonesia.

Nazir, M., 2003. Metodologi Penelitian Bisnis, Cetakan 5. Jakarta : Ghalia.

Pamitra, T., 2001. Perilaku Konsumen dan Komunikasi Pemasaran. Bandung: PT Remaja Rosda Karya.

Purnomo, H., 2003. Pengantar Teknik Industri.

Rambat, L., 2001. Manajemen Pemasaran Jasa: Jasa Teori dan Praktik. Edisi Pertama, Salemba Empat, Jakarta.

Rangkuti, F., 2006. Measuring customer satisfaction: gaining Customer Relationship strategy (Teknik mengukur dan strategi meningkatkan kepuasan pelanggan). Jakarta: PT Gramedia Pustaka Utama.

Ruky, A.S., 2002. Sistem manajemen kinerja. Gramedia Pustaka Utama.

Santoso, S., 2002. Buku latihan SPSS statistik multivariat. 
Simanjuntak., 2005. Pengaruh Budaya Organisasi terhadap Kepuasan Kerja. Jakarta : Gramedia Pustaka Utama.

Sugiarto, E., 2002. Psikologi Pelayanan Dalam Industri. PT. Gramedia Pustaka Utama: Jakarta.

Sugiyono., 2004. Statistik Untuk Penelitian. Cetakan Keenam. Bandung :Alfabeta,

Sunarto, S., 2003. Perilaku Konsumen. Yogyakarta: AMUS Yogyakarta dan CV Ngeksigondo Utama.

Supranto, J., 2001. Pengukuran tingkat kepuasan pelanggan.
Suranto, A.W., 2005. Komunikasi Perkantoran. Yogyakarta: Media Wacana.

Tim STIE Pembangunan Tanjungpinang., 2014. Panduan Penulisan Skripsi dan Panduan Penulisan Jurnal. Tanjungpinang: STIE Pembangunan Tanjungpinang.

Tim Unesa., 2000. Pedoman Penulisan Artikel Jurnal. Surabaya: Unesa Press.

Ujang, S., 2003. Perilaku Konsumen, Teori dan Penerapannya.

Perilaku dan Budaya Organisasi,
Bandung : Refika Aditama

